\title{
ビデオ蛍光顥微鏡を用いた細胞内遊離カルシウムイオン 濃度分布測定におけるバックグラウンド蛍光の補正法
}

\author{
宮川厚 夫* \\ (1992 年 6 月 4 日受理)
}

\begin{abstract}
蛍光顥微鏡亡画像処理を用いた, 蛍光性カルシウム指示薬 Fura-2 による細胞内遊離カルシウムイオ ン濃度分布測定で, 細胞周辺部のカルシウムイオン濃度が異常に高濃度に推定される場合が多い。これ は, 蛍光影微鏡でしばしば見られる蛍光像のハレーションが原因である.このため, 細胞の透過光像と, カルシウムイオン分布測定時の蛍光像を重ね合わせて表示して, バックグラウンド蛍光強度と共に, 八 レーション強度を指定できるようにした。更にハレーション強度以下の蛍光強度の場合, カルシウムイ オン分布を表示しないようにすることで, 細胞像とよく一致した分布像を得ることが容易になった。こ のバックグラウンド蛍光推定法は, カルシウムイオン以外に, 同様な蛍光性指示薬が用いられるマグネ シウムやナトリウムイオン, $\mathrm{pH}$ などでも利用可能である.
\end{abstract}

\section{1 緒言}

生きている単一の細胞における, 紐胞内遊離カルシウ ムイオン濃度 $\left(\left[\mathrm{Ca}^{2+}\right]_{\mathrm{i}}\right)$ の分布が, Fura-2 や Indo-1 などの蛍光性プローブ試薬を用いて広く測定されてい $る^{1) \sim 3)}$. しかし, 測定された $\left[\mathrm{Ca}^{2+}\right]_{\mathrm{i}}$ の正確性にはプ ローブ試薬と細胞内タンパク質の相互作用など4), 幾つ かの問題点が残されている.

その一つが, 蛍光䫓微鏡を用いて, 細胞や組織切片の $\left[\mathrm{Ca}^{2+}\right]_{\mathrm{i}}$ 分布を測定した場合, 試料周辺部の $\left[\mathrm{Ca}^{2+}\right]_{\mathrm{i}}$ が異常な高濃度を示す場合があることである．この現象 のため, 細胞膜に存在するカルシウムチャンネルなどが オープンして, 実際に細胞膜直下の $\left[\mathrm{Ca}^{2+}\right]_{\mathrm{i}}$ が上昇し たときなどとの識別が困難になる．この現象は, バック グラウンド蛍光強度をわずかに変化させただけで, 微妙 に変化するので, アーチファクトであると推定できる が, 真の濃度を求めることは困難である.

この細胞周辺部の現象は, 蛍光䫓微鏡でしばしば見ら れる蛍光像のハレーションが原因である. すなわち, 単 に蛍光像からだけでバックグラウンド蛍光強度を推定す ると, ハレーション部分まで細胞として $\left[\mathrm{Ca}^{2+}\right]_{i}$ 計算 に含める場合が多いためである.

既報 ${ }^{5}$ で報告した $\left[\mathrm{Ca}^{2+}\right]_{i}$ 分布と䫓微鏡画像を重ね合 わせて表示できるシステムを利用して, ハレーション部

* 浜松医科大学メディカルホトニクス講座: 431-31 静 岡県浜松市半田町 3600
分を明確に区別することができるようになった。この報 告では $\left[\mathrm{Ca}^{2+}\right]_{\mathrm{i}}$ 分布測定機器のハードウエアには手を 加えず，プログラムを改良することで，正確なバックグ ラウンド蛍光強度を推定し, 顕微鏡像とよく一致した $\left[\mathrm{Ca}^{2+}\right]_{\mathrm{i}}$ 分布像を求める方法について述べる.

\section{2 実験}

\section{$2 \cdot 1$ 测定㙨器と実鈋材料}

測定機器は文献6) と同じく, 倒立型落射蛍光影微鏡 IMT-2-21-CA3（オリンパス), SIT 撮像管 C2741-08 (浜松ホトニクス), フレームメモリ DVS-3000 (浜松ホ トニクス), 及び, パーソナルコンピュータ PC-9801 VX41（日本電気）で構成される. 又, 蛍光性カルシウ 么指示薬 Fura-2 などの試薬類も, 文献) と同様な種類 を用いた。測定に用いる培養器具や, 薬物刺激装置も文 献5)同じである。

又, 測定に使用した培養細胞も，文献6)と同じマウス のニューロブラストーマとラットのグリオーマのハイブ リッド細胞 NG108-15 である. 培養条件と, Fura-2の 細胞へのロードも文献吕と同一に行った.

\section{$2 \cdot 2$ プログラム}

従来のバックグラウンド蛍光強度推定は, 蛍光像を擬 似カラーで表示して, 細胞から離れた位置の蛍光強度を 読み取り，バックグラウンドとしていた（Fig. 2A 参 照). 
文献) えるようにプログラムを改良したので，顕微鏡像がバッ クグラウンド蛍光強度の推定にも利用できるように, 次 の 3 点の処理を追加した. 1 番目は, バックグラウンド 蛍光強度の推定時に, 透過光による顕微鏡像と重ねて蛍 光強度を表示できるようにしたことである. 2 番目は， バックグラウンド蛍光強度として, 従来の 2 波長分の 蛍光強度に加えて, ハレーション強度を新たに取得する ようにした. 3 番目は, $340 \mathrm{~nm}$ と $360 \mathrm{~nm}$ のいずれか の蛍光強度がハレーション強度以下の場合, 蛍光強度比 を計算せず， $\left[\mathrm{Ca}^{2+}\right]_{\mathrm{i}}$ を表示しないようにした。従っ て, 蛍光強度比の計算式は, 式( 1 )となる.

$$
R=\left\{\begin{array}{lr}
\frac{I_{340}-B_{340}}{I_{360}-B_{360}} & \text { ただし, } I_{340} \geqq \mathrm{Hal} \text { or } I_{360} \geqq \mathrm{Hal} \\
0 & \text { ただし, } I_{340}<\mathrm{Hal} \text { or } I_{360}<\mathrm{Hal}
\end{array}\right.
$$

ただし， $R$ は蛍光強度比， $I_{340}$ と $I_{360}$ は, それぞれ, 波長 $340 \mathrm{~nm}$ と $360 \mathrm{~nm}$ における蛍光強度, $B_{340}$ と $B_{360}$ は，それぞれ，波長 $340 \mathrm{~nm}$ と $360 \mathrm{~nm}$ におけるバック グラウンド蛍光強度, 又, Hal はハレーション強度であ る.

\section{$2 \cdot 3$ 测 定}

測定は，文献5に示した手順で行った。ただし，䫓微 鏡像の入力には, 必ず透過光像が必要である. ノマルス キ一微分干渉像などは, 顕微鏡像が蛍光像からずれるた め, 好ましくない. 又, 䫓微鏡像と蛍光像をよく一致さ せるために, 透過光像の入力後, 蛍光測光の前にピント を合わせ直すことや，機械的な振動により，焦点の移動 や試料細胞の移動が生じないように注意する必要があ る.なお, 顕微鏡像の入力にも, 蛍光観察用の超高感度 の SIT カメラを用いる関係上, 強すぎる光を当てない ようにする注意も必要である.

バックグラウンド蛍光とハレーションの強度の推定 は, 次の順序で行う (Fig. 1). 最初に Fig. 1A に示し たように，顕微鏡像を表示させ，赤と水色で示された水 平カーソルをバックグラウンド蛍光を推定したい場所ま で上下に移度する. 次に，カーソルで指示した位置の透 過光強度が黄色の線で, $340 \mathrm{~nm}$ と $360 \mathrm{~nm}$ の蛍光強度 が，それぞれ，水色と緑色の線で表示される（Fig. 1B). そして, 透過光強度を見ながら, 垂直カーソルを 左右に動かして, 細胞の縁まで移動する. 最後に, 3 本 の水平カーソルを, それぞれ, 上下し, 2 波長のバック グラウンド蛍光強度とハレーション強度を決定する
(Fig. 1C). 通常, バックグラウンド蛍光は, 細胞から 十分に離れた位置の蛍光強度とし, ハレーションは垂淔 カーソル位置の蛍光強度とする.

\section{3 結果と考察}

\section{$3 \cdot 1$ 従来法によるバックグラウンド蛍光強度推定法 と $\left[\mathrm{Ca}^{2+}\right]_{\mathrm{i}}$ 分布}

Fig. 2A に, 通常行われている, 従来のバックグラウ ンド蛍光推定法を示した．図は左側のウィンドウに擬似 カラーで表示された蛍光像上で，バックグラウンド蛍光 強度を推定したい位置へ水平カーソルを移動し, 右側の ウィンドウに蛍光強度のプロフィルを表示した状態であ る. その後, 水平カーソルをバックグラウンド蛍光と思 われるところまで.上ささ，バックグラウンド蛍光の強 度を指定する.それぞれの波接についてこの操作を行 う. 市販の測定機器により, 表示方法は様々であるが, 原理的には同じ方法である.

この方法で, バックグラウンド蛍光強度は, $340 \mathrm{~nm}$ が相対值として $49,360 \mathrm{~nm}$ が 54 と見積もられた（Fig. $3 \mathrm{~A}, \mathrm{~B})$. ところが, 細胞の蛍光像には八レーションによ るすそがあり，どこが細胞の境界であるか不明りょうで ある. 従って, 同じ測定データを用いて, この前後で值 を変化させてみると Fig. 2B, C のような結果が得られ る. 蛍光像のすその少し.上部をバックグラウンドとする と, $340 \mathrm{~nm}$ では $75,360 \mathrm{~nm}$ では 25 とも推定できる. このバックグラウンド蛍光強度で $\left[\mathrm{Ca}^{2+}\right]_{\mathrm{i}}$ 分布を計算 すると, Fig. 2B のように細胞周辺部と神経突起が低 $\left[\mathrm{Ca}^{2+}\right]_{\mathrm{i}}$ を示す. 又, $340 \mathrm{~nm}$ のバックグラウンドをわ ずかに下げて，25とすると，Fig. 2C に示したよう に，全く異なった様子になる.

一方, 細胞内部の $\left[\mathrm{Ca}^{2+}\right]_{i}$ は, バックグラウンド強 度を変化させても，318～522 $\mathrm{nM}$ と細胞周辺部ほどの 変化は生じていない，このように，バックグラウンド蛍 光強度をわずかに変化させただけで, 細胞周辺部の $\left[\mathrm{Ca}^{2+}\right]_{\mathrm{i}}$ は大きく変動する.

\section{$3 \cdot 2$ 重ね合わせ法によるバックグラウンド蛍光強度 推定例}

Fig. 3 に従来法と重ね合わせ法で求めた 2 種類のバ ックグラウンド蛍光強度を使用して, $\left[\mathrm{Ca}^{2+}\right]_{\mathrm{i}}$ 分布を計 算した例を示した. Fig. 1 の方法で求めたバックグラウ ンド蛍光強度は, $340 \mathrm{~nm}$ のとき $24,360 \mathrm{~nm}$ で 16 であ り, ハレーション強度は 120 である.この重ね合わせ 法によるバックグラウンド強度は, 従来法より低い俻で ある.これは, 従来法が細胞の存在しない背景に, ノイ 


\section{A}

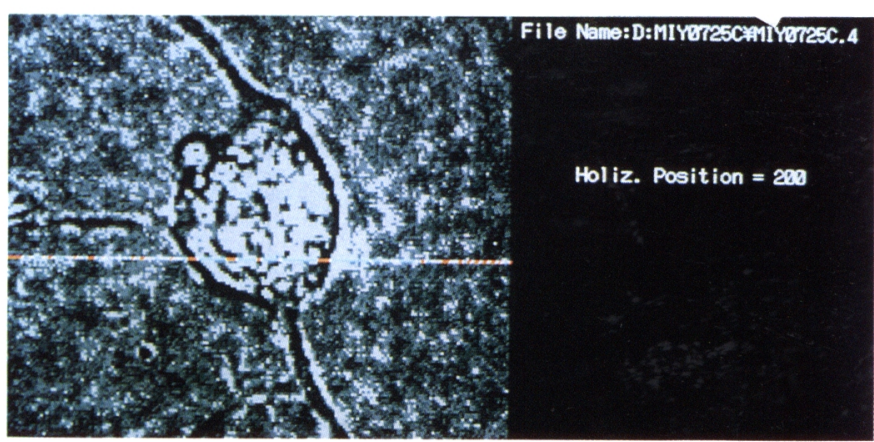

B

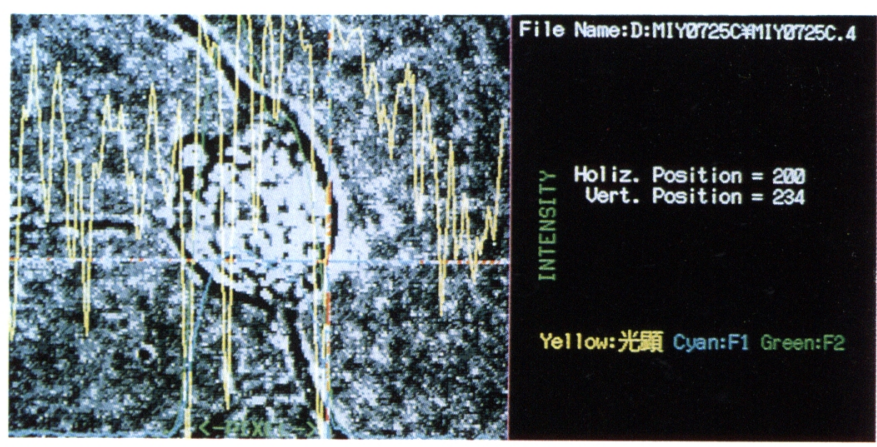

$\mathrm{C}$

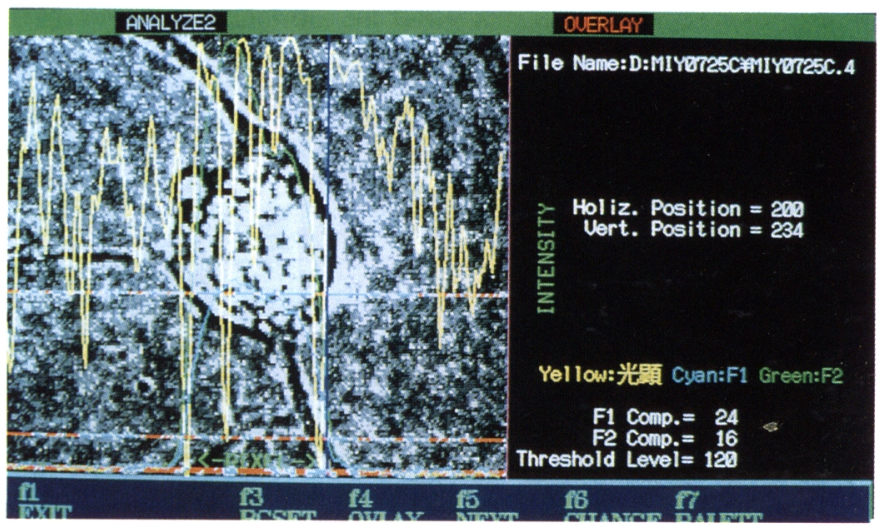

Fig. 1 Improved estimation method of background fluorescence intensity using microscopic imagery

A. First step of background fluorescence estimation shows the microscopic cell image by transmitted light on VDT at 7 levels of black-and-white. Then, horizontal cursor representing the red and cyan color line was moved into position for background estimation. B. After set of the position, the transmitted light intensity of microscopic image (yellow line), the fluorescence intensity at $340 \mathrm{~nm}$ (cyan line) and $360 \mathrm{~nm}$ (green line) were displayed. The vertical cursor was shifted to right and left, and adjusted at the edge of the cell. C. Three horizontal cursor shows on the VDT. The first cursor indicated the background fluorescence intensity at 340 $\mathrm{nm}$, and the second was the background at $360 \mathrm{~nm}$. These cursors were moved to background intensity which was estimated at separately from the cells. The third cursor was transferred at the cross point of the vertical cursor line and the fluorescent profile line at $340 \mathrm{~nm}$ or $360 \mathrm{~nm}$. This cross point indicate the halation intensity. 

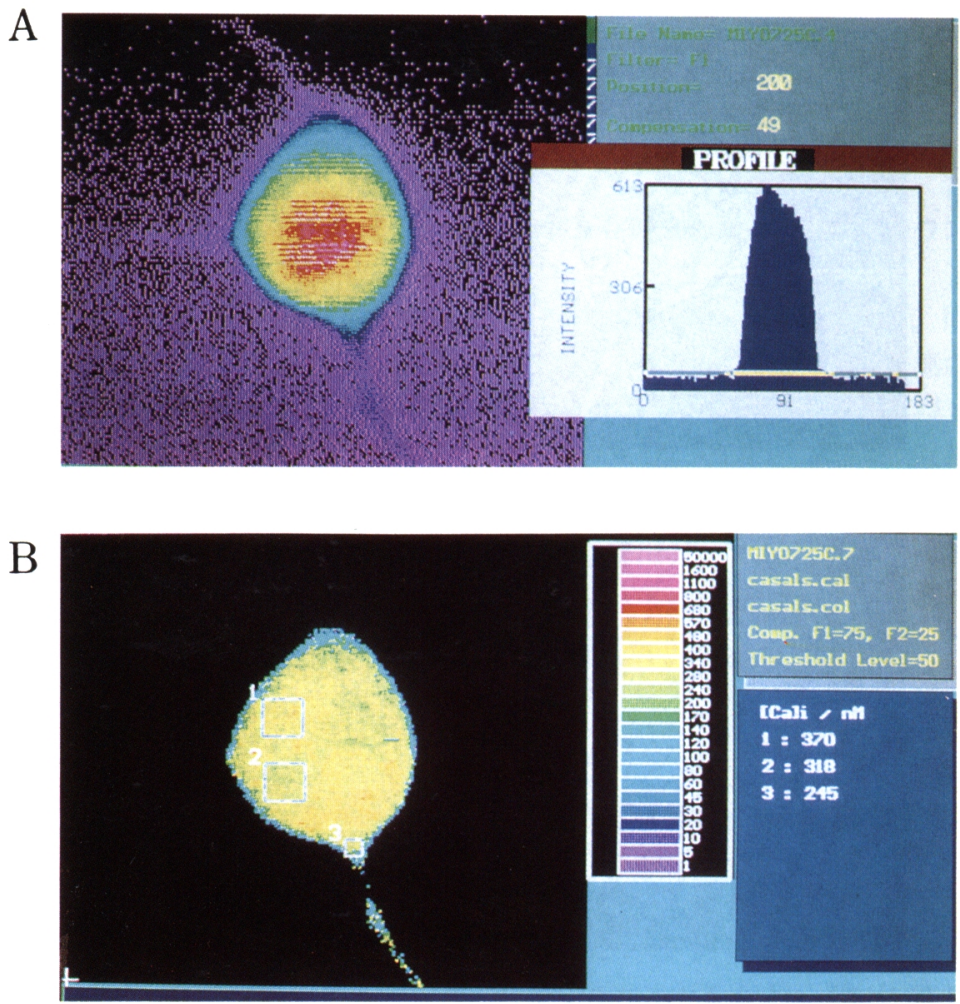

$\mathrm{C}$

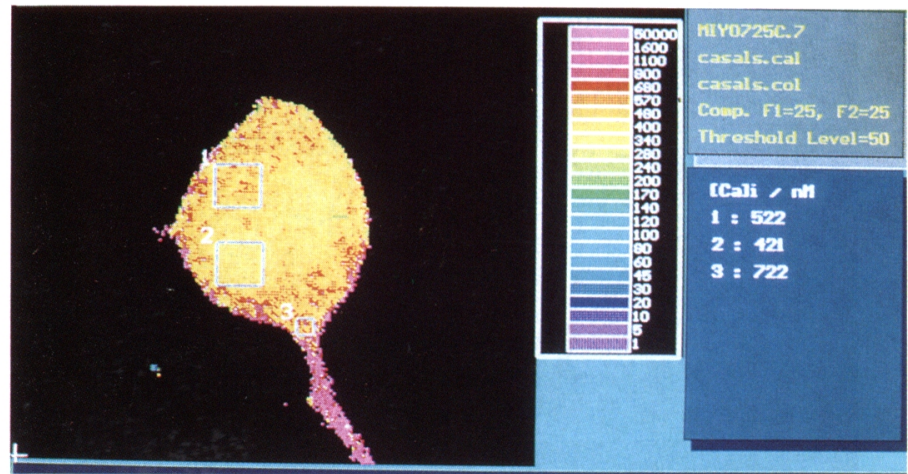

Fig. 2 Conventional estimation method of background intensity and $\left[\mathrm{Ca}^{2+}\right]_{\mathrm{i}}$ distribution

A. Conventional estimation method of background fluorescence intensity. Fluorescent image illustrated with pseudocolor on the left window. Next step, horizontal cursor was moved up and down, and set in position for the estimation. Fluorescence intensity shows in the right window. The horizontal cursor was transferred to background intensity level. This operation was done at $340 \mathrm{~nm}$ and $360 \mathrm{~nm}$ for both image data. B. The $\left[\mathrm{Ca}^{2+}\right]_{i}$ distribution was done calculated using the background value 75 at $340 \mathrm{~nm}$ and that of $25 \mathrm{at} 360 \mathrm{~nm}$. C. The $\left[\mathrm{Ca}^{2+}\right]_{\mathrm{i}}$ distribution calculated for a background of 25 at both $340 \mathrm{~nm}$ and $360 \mathrm{~nm}$. Comparing B with $\mathrm{C}$, the $\left[\mathrm{Ca}^{2+}\right]_{\mathrm{i}}$ express plausible distribution. Around of the cell point out very different $\left[\mathrm{Ca}^{2+}\right]_{\mathrm{i}}$. However, the inner part of the cell shown has the almost same concentration. The measurement conditions: objective lens, $\times 20$; intermediate lens, $\times 1.5$; photoeyepiece lens, $\times 6.7$; and integration times 4 . The numbers shown on the right side of the VDT is the $\left[\mathrm{Ca}^{2+}\right]_{\mathrm{i}}(\mathrm{nM})$ indicated by the square cursor in the distribution image. 
A

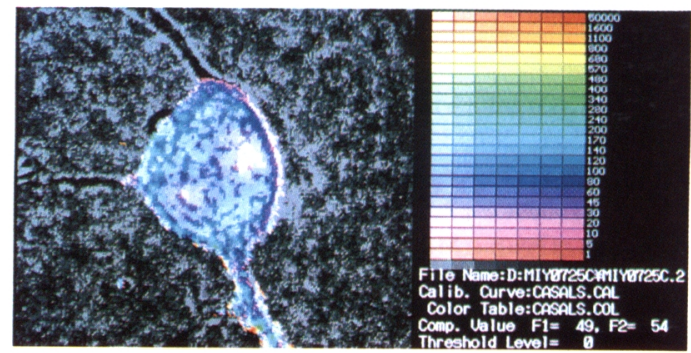

C

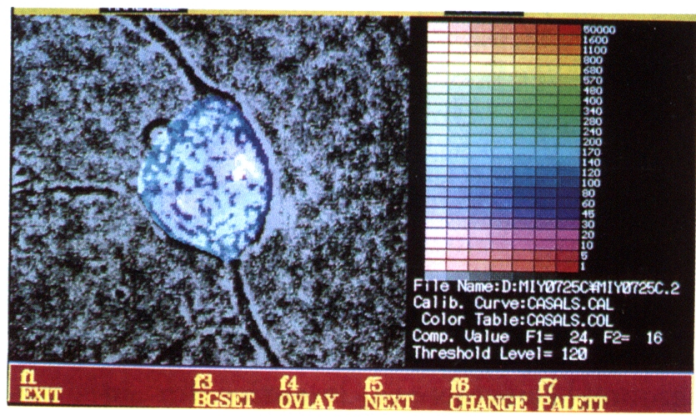

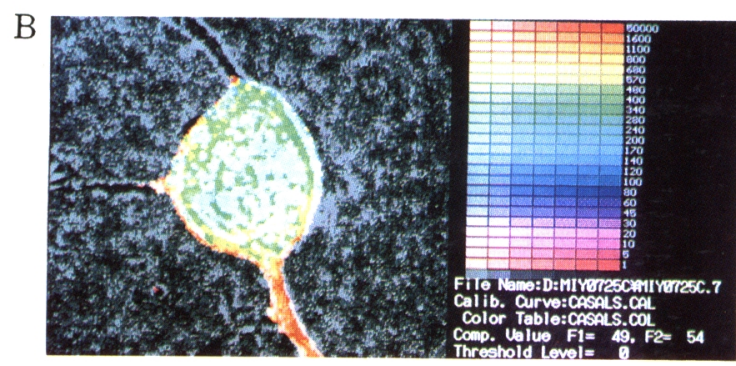

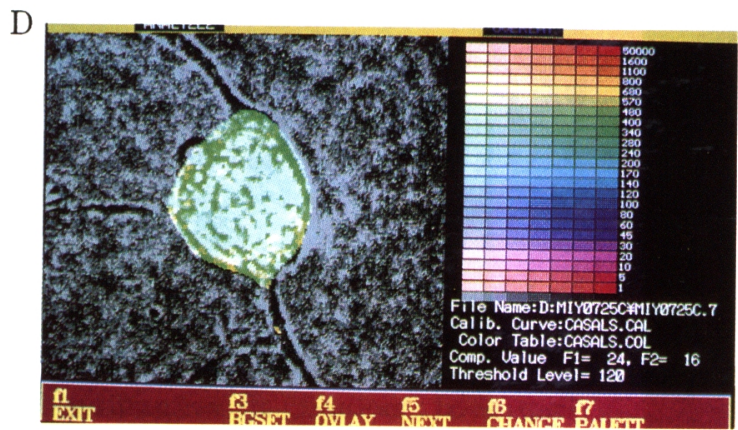

Fig. 3 Comparison of two estimation methods for background fluorescence intensity

A, B. Conventional estimation method. C, D. Improved estimation method. $\left[\mathrm{Ca}^{2+}\right]_{\mathrm{i}}$ distribution of the A and $\mathrm{B}$ was pushed beyond the border of the superimposed cell image. However, $\mathrm{C}$ and D images show good correspond with $\left[\mathrm{Ca}^{2+}\right]_{\mathrm{i}}$ distribution and the cell image obtained by transmitted light. A, C and B, D are the same data, respectively. The measurement conditions are the same as Fig. 2. A and C, before stimulation with $50 \mathrm{mM} \mathrm{KCl}$; $\mathrm{B}$ and $\mathrm{C}$, after the stimulation at $8 \mathrm{~s}$.

ズ的な $\left[\mathrm{Ca}^{2+}\right]_{\mathrm{i}}$ 分布を表示しないように,やや高いバ ックグラウンド強度を指定する傾问があるためである。 細胞像上 $\left[\mathrm{Ca}^{2+}\right]_{\mathrm{i}}$ 分布在重权合わせて表示してみる 上, 従来のバックグラウンド推定法の問題点が明確にな っている。従来法によるFig. 3A，B では細胞からはみ出 した部分にまで $\left[\mathrm{Ca}^{2+}\right]_{\mathrm{i}}$ 分布が表示されている。しか も, Fig. 3B では, 細胞の存在しない部分の $\left[\mathrm{Ca}^{2+}\right]_{\mathrm{i}}$ 分 布が上昇して見える.

・方，重权合わ世法で決定したバックグラウンド蛍光 上ハレーション強度を使用した場合は, 細胞像と $\left[\mathrm{Ca}^{2+}\right]_{i}$ 分布はよく一致している(Fig. $\left.3 \mathrm{C}, \mathrm{D}\right)$. そし て, 細胞像之一致した部分の $\left[\mathrm{Ca}^{2+}\right]_{\mathrm{i}}$ 分布は, 従来法 上重社合わせ法のビちらのバックグラウンド蛍光強度を 用いても，ほぼ同し濃度を示している。しかし，この例 ではバックグラウンド蛍光と八レーションの強度を細胞 体の部分で推定したため, 神経突起部分の $\left[\mathrm{Ca}^{2+}\right]_{\mathrm{i}}$ 分 布は表示されていない。

\section{$3 \cdot 3$ 考 察}

$\left[\mathrm{Ca}^{2+}\right]_{\mathrm{i}}$ 分布測定上の問題点の一つである, 細胞周辺 部の異常な $\left[\mathrm{Ca}^{2+}\right]_{\mathrm{i}}$ が, 細胞構造之 $\left[\mathrm{Ca}^{2+}\right]_{\mathrm{i}}$ 分布の対 応を取ることで防止できるようになった。同様な現象 が, $\mathrm{Ca}^{2+}$ 以外に, $\mathrm{Mg}^{2+}$ や $\mathrm{K}^{+}, \mathrm{Na}^{+}, \mathrm{Cl}^{-}$などでも生 じることを考えれば，広い応用領域があるであるう。 又, 細胞だけにとどまらず，組織切片などでも周辺部の $\left[\mathrm{Ca}^{2+}\right]_{\mathrm{i}}$ 異常が恋められることが多いため, 細胞や組織 中での $\mathrm{Ca}^{2+}$ の生理的機能や役割を解明するために重 要な実験手段になるであろう。

1 個の細胞でも，例えば，神経細胞の細胞体之神経突 起のように, 細胞の部分により蛍光強度が異なれば, 八 レーション強度も異なる。従って,この報告で述べた方 法では, 観察したい場所によりハレーション強度を最適 化する必要がある. Fig. 3 に示したように, 神経細胞で は, 細胞体と神経突起の両方の $\left[\mathrm{Ca}^{2+}\right]_{\mathrm{i}}$ 分布在同時に 正確に表示するのは困難であった。

コンピュータープログラムによる細胞の輪郭抽出が行 
えれば, この問題点を解決し, しかも, 自動的にバック グラウンド蛍光強度を決定できる叮能性がある．輪郭の 抽出を行うには不均一な照明に上る背景を局所的変換》 により補正し，二次元二次微分 ${ }^{8)}$ を行うことで叮能であ る.しかし，今回は輪郭抽出は試みなかった。サンプル が弧立した1個の細胞であるとは限らないことや，不 均一な照明により常に抽出が成功するとは限らないため である. 又, 使用したパーソナルコンピュータの性能か ら，処理に時間がかかりすぎるという問題もあり，今後 の課題としたい.

測定機器の画像処理プログラムの改良を手伝っていただ いた牧野 徹氏|オリンパス光学工業(株)バイオメディカ ルリサーチセンター| と実験にご協力いただいた尾碕一穂 博士 \{オリンパス光学工業(株)第二開発部\}に感謝しま す.

\section{文献}

1) G. Grynkiewicz, M. Poenie, R. Y. Tsien: J. Biol. Chem., 260, 3440 (1985).

2) R. Y. Tsien, M. Poeni: Tr. Biochem. Sci., 11, 450 (1986).

3) A. Ogura, M. Nakazawa, Y. Kudo: Neurosci. Res., 12, 606 (1992)

4) M. Konishi, A. Olson, S. Hollingworth, S. M. Baylor: Biophys. J., 54, 1089 (1988).

5) 宮川厭夫: 分析化学, 41, T113 (1992).

6）宮川厚夫, 牧野 徹, 垃川彰, 尾碕一穂: 分析化 学, 38, 643 (1989).

7) 河田聡, 埜田友也, 涬茂夫: インターフ エース, 137, 172 (Oct., 1988).

8) 河田聡, 南茂犬: インターフェース, 137, 192 (Oct., 1988).

Improved method of estimating background fluorescence intensity for intracellular free calcium ion distribution with video fluorescence microscopy. Atsuo Miyakawa (Department of Medical Photonics, University of Hamamatsu School of Medicine, 3600, Handa-cho, Hamamatsu-shi, Shizuoka 431-31)

The distribution of intracellular free calcium ion concentration $\left(\left[\mathrm{Ca}^{2+}\right]_{i}\right)$ is measured using a fluorescent calcium indicator dye and video fluorescence microscope. In many cases, the $\left[\mathrm{Ca}^{2+}\right]_{\mathrm{i}}$ distribution around cells is unusually concentration. This well-known phenomenon is due to the halation from the fluorescent cell images. The $\left[\mathrm{Ca}^{2+}\right]_{\mathrm{i}}$ distribution containing the halation is usually calculated by a conventional background estimation method. In the improved method, three types of background fluorescence intensity are distinguished. Two types are the same as the conventional background intensity. The third is halation intensity. The estimation of halation intensity is performed as follows. The first step is the display of superimposed fluorescent image and cell image obtained by transmitted light microscopy. The second step specifies the halation intensity by the fluorescence intensity at the edge of the cell. The $\left[\mathrm{Ca}^{2+}\right]_{\mathrm{i}}$ distribution is calculated only from that fluorescent intensity which exceeds the halation intensity. By this improved estimation method, the $\left[\mathrm{Ca}^{2+}\right]_{\mathrm{i}}$ distribution correspondence to the microscopic cell images could be obtaind.

(Received June 4, 1992)

\section{Keyword phrases}

intracellular free calcium ion; Fura-2; fluorescence microscope; video image processing. 